\title{
Relations and Emotions beyond the Boundaries in the Post Crisis Era - An Analysis of the Impact of Selected Variables on the Indian Stock Market
}

\author{
Dr. Pooja Yadav (Corresponding Author) \\ Assistant Professor, MDU-CFPAS, Sector 40, Gurugram \\ Maharshi Dayanand University, Rohtak, India. \\ Nitin Huria \\ Research Scholar, MDU-CFPAS, Sector 40, Gurugram \\ Maharshi Dayanand University, Rohtak, India.
}

\begin{abstract}
From a decade or so Indian continent has become the centre of attraction in the global economies. This changed outlook is due to the fact that India embraces vast availability of resources and opportunities which makes it the most vibrant global economy in the current scenario of worldwide sluggishness. On this path of growth and prosperity India is showing stiff commitments and competitive edges with developed as well as emerging countries. To be more specific, during this voyage in the Asia pacific region recently on one side India has seen stronger bonding with some of its old mates like Japan but on the other part it has faced strain like situation from its stronger competitor contender china on the same time. Hence, in this context the main aim of this paper is to examine the long run and short run equilibrium impacts of Japan and Chinese stock index as well as macroeconomic variables impact on Indian stock market. This paper finds the presence of both long and short run equilibrium impacts from China and Japan to India. In case of Japanese financial market (Nikki 225) has a trivial negative but significant long run impact whereas, the Chinese stock index (SSE composite) is operating at the short run with the same mild negative but significant impact on the Indian stock market. The results of the impact of macroeconomic variables find the existence of long run as well as short run equilibrium from some of the selected variables on Indian stock market.
\end{abstract}

KEYWORDS: Continent, Outlook, Embrace, Sluggishness, Stiff, Voyage. 


\subsection{INTRODUCTION}

Today in the global prologue India asserts an enduring position amongst the top competitive nations. The country with its strong basic fundamentals and diversities is no doubt entring into a fresh panorama to transform itself more strappingly for the future upbringings and robust intercontinental articulation. On this voyage in the recent few years the surpassed of the financial crisis has changed several things worldover. But to cope up with this india adhere and persist on its previous policies of liberalization and striding forward along with its companions.

In the asia pacific region, India has a strong bonding with Japan and China in terms of different elements. The advance economy Japan is India's friend from decades and providing it support related to several aspects. As we all know that during the tenure of this designated government quite a number of policies has been initiated and Japan hold a solid stand in almost all the initiatives whether it is Make in India or Digital India.whether it is transportation support or financial prop up. On the other hand the emerging neighbourhood China has good trade relations with india. But in the current period it has faced international level strain like situation from its stronger competitor contender china. Hence, in this regard a need was felt to study the impacts of these two economies on the stock market of india in the post crisis era. An attempt is made to discover the tone of the long run or short run elasticises if present.

As there is no doubt that the financial market in India is settled by the day to day factors and the information dissemination of assorted events sets the mood across the segments in the modernize environment. Therefore, the bilateral trades transpired between these countries could be a bridge of passing positive and negative waves of local macroeconomic or political conditions.

\subsection{LITRATURE REVIEW}

In the litrature the relationship among the nations on the global horizon has been tested and portrayed in terms of varied views. But for the purpose of this research we are mainly concerned with highlighting the casual relationship among the selected countries in terms of selected factors. a brief consolidation of the facts and findings of different authors has been presented below:

R. D. Gay (2008) examined the relationship between stock prices and macroeconomic variables among the BRIC economies. For this purpose the author took monthly data of exchange rate, oil price, and the closing prices of the national indexes. The paper revealed that no significant relationship was present between respective exchange rate and oil price on the stock market prices in any of the BRIC country.

G. Sanati (2010) studied integration of domestic and international fronts of indian financial market during post liberalization period. The application of J-J approach disclosed the existence of comovement at domestic level. On the part of international horizon only short-term inter-bank rate, was found significantly cointegrated whereas, treasury bill 91 shown weak form of integration.

A. Mobarek tried to discover the cross-country return co-movement between ten developed and emerging nations vis-à-vis a total country sample composed by 20 countries. The Geweke (1982) methodology along with a set of pooled cross-country time-series regressions were utilized to detect and explain the changes in stock market integration. The results of this study also find in align with other findings of increased stock market integration.

P. Joshi (2011) examined the return and volatility spillover between selected Asian stock markets. for this objective (GARCH-BEKK) model was applied on the daily data obtained over the period 20072010. The findings disclosed the existence of weak form of bidirectional return, shock, and volatility spillover among most of the selected stock markets.

P. Srikanth and Dr. K. Aparna (2012) studied the level of integration between selected major world stock markets. for this objective month-wise average prices of BSE-Sensex, NYSE, NASDAQ, S\&P500, HangSeng, Nikkei225, SSE Composite index and FTSE100 over the period 2000 to 2009 were collected. The paper finds the presence of significant level of integration between domestic and international financial markets. further, it was found that the Indian market has shown strong correlation with the chinese market whereas the japanese index has no influence on the indian market. 
A. Bhunia and A. Das (2012) tried to capture the relations of indian stock market with the other South Asian markets. The daily data from 2002 to 2011 of the respective indices of countries under consideation was utalized for the entailed objective. The results indicated the presence of both long and short run associations among the selected Asian markets. similar results were found by the studies $\mathbf{K}$. Lingaraja et. al. (2012), P. Chougala1 and H.S. Srivastsa, B. S. Veerappa, on the same region.

R. Glick and M. Hutchison (2013) studied the asset market linkages among China and Asia and find these linkages have shifted during and after the global financial crisis of 2008-2009. Their findings reported weak form of cross-country linkages in longer-term interest rates, but much stronger linkages in equity markets. Further it was also documented that the correlation strength of equity market prices between China and other Asian countries had increased during the crisis period and has remained high in recent years. Moreover, the transmission of U.S. equity returns to Asian countries decreased after the crisis.

M. Anees and S. Kumar (2014) investigated the weak form of market efficiency among the three major Asian countries i.e. Japan, India, and China. For this purpose the authors selected data of daily and weekly closing prices of the respective national indexes over the period 2009 to 2014. Their results revealed the random walk behaviour in the three markets and the markets shown weak form of efficiency.

A. Bhatia (2014) studied the nature of volatility and inter linkages among the two major emerging economies i.e. india and china. The sample size consisted of monthly closing prices of BSE Sensex and SSE composite index over the period 2004 to 2012. Finding of the paper revealed unidirectional causality running from Chinese stock market to Indian stock market during the sample period. Further, both the countries faced their highest level of volatility during the year 2008 .

S. A Patel (2014) examined the integration of Indian stock market with other selected asian markets. For this purpose monthly data of the national stock indices was used during the period 1997-2012. Finding of the paper unveiled the existence of long run equilibrium relationship among Asian markets. further it uncovered the casuality direction running from Sri Lanka, Japan, Singapore, and China.

M Babu, C Hariharan and S Srinivasan (2016) endeavoured to test the linkages among some of the Asia pasific markets by using daily data of the national indexes from 2009 to 2014 . Their findings revealed the presence of long run cointegration of some of the selected markets whereas in the short run few markets shown unidirectional relationship with SSE composite index.

S. Arslanalp et. al. (2016) tested the spillover impact of china's growing influence on asian financial markets using event studies and an empirical analysis. The empirical analysis utalized daily data from 2001 to 2014 to support evidences. Results drawn from both the analysis divulged that there is a rising trend of financial spillover from china to asian equity and foreign exchange markets. the main transmission paths held responsible to be trade linkages, but direct financial linkages playing an important role. Although china's influence on regional markets is not yet to the level of the United States, but comparable to that of Japan. If China-related shocks are coupled with global risk aversion episodes the impact on regional markets could be much larger.

\subsection{OBJECTIVES OF THE STUDY}

- To study the long run and short run equilibrium impact of Japan and Chinese financial markets on Indian stock market.

- To determine the impact of selected macroeconomic variables of Japan and china on Indian stock market.

- To trace the presence of temporal causality from the selected variables to India. 


\subsection{DATA AND METHODOLOGY}

\subsection{Sources of Data:}

In this study secondary data is used which has been collected from various websites such as:

- Yahoo finance.

- investing.com

- World Bank, OECD etc.

\subsection{Period of Study:}

In the present study a horizon of 07 years 6 month from 01/01/2010 until 06/28/2017 (consisting of monthly observations of the selected sample series) is used for the testing rationale.

\subsection{Sample Variables:}

The following sample variables have been resorted to form the part of the study:

\begin{tabular}{|ccc}
\hline India & Japan & China \\
& Nikki 225 Stock Index & SSE Composite Stock Index \\
BSE Nifty 50 Stock Index & Balance of Trade & Foreign Exchange Rate \\
Inflation Rate
\end{tabular}

\subsection{Estimation Specification}

This study rely upon the autoregressive Distributed lag (ARDL) bounds testing technique of cointegration invented by Pesaran and Pesaran (1997); Pesaran et al. (2000), and latter on by Pesaran et al. (2001) to trace the long run and short run equilibrium impacts of selected macroeconomic variables as well as national stock indexes of Japan and China on Indian stock market. The motive behind inclination towards this procedure rather than the tradition co-integration approaches (Engle and granger, 1987) and Johansen and Juselius (1090) is several folds. First of all this approach is relatively new and recently developed. The ARDL model can be applied without disquieting about the order of integration $I(0), I(1)$ or a combination of both (Pesaran and Pesaran1997). Secondly, this technique is more unwavering in determining co-integration relations for small data sample sets such as apply in our case as compared to the traditional approaches (Haug, 2002). Third, in the situation of endogeneity of some of the independent variables in the model the bound testing method generally offer dispassionate long run estimates and valid t statistic (Narayan, 2005).

Fourth, the unrestricted version of this model automatically captures the optimum quantity of lags for the data engendering process in a general to specific framework arrangement. (Laurenceson and Chai, 2003). Fifth, the short run estimates integrating of short run adjustment information can be derived from ARDL methodology through a straightforward linear conversion. However, through the fixed numeral criteria adaptations under the ARDL model can be implemented to overcome the diagnostic model fitting issues Pesaran and Shin (1999).

Fundamentally, the essence of the ARDL model architecture lies in running and analyzing two sequential procedure estimates to unveil the long run relationship. On the first note, the F statistic is being retrieved and decision about the long run co-integration among the selected variables under estimation pertain upon the tabularized upper and lower bound critical values by Pesaran et al. (2001). The null hypothesis of no co-integration follows $\alpha 2=\beta 2=\alpha 3=\beta 3=0$ and the alternative hypothesis 
of co-integration among variables follows $\alpha 2=\beta 2=\alpha 3=\beta 3=0$. Further a comparison of $F$ statistic with upper and lower bounds is being made to evident the existence or no existence of co-integration. The next step trails the estimation of long run and short run models.

\subsection{EMPIRICAL FINDINGS AND DISCUSSION}

Graph 1 shows the behavior of the selected variables over the sample period. As we can observe that the movement of all the variables has a different trend. This initial glimpse at the data sets reveals that some of the variables follows a trend whereas for some variables the pattern have an essence of randomness.

Graph 1
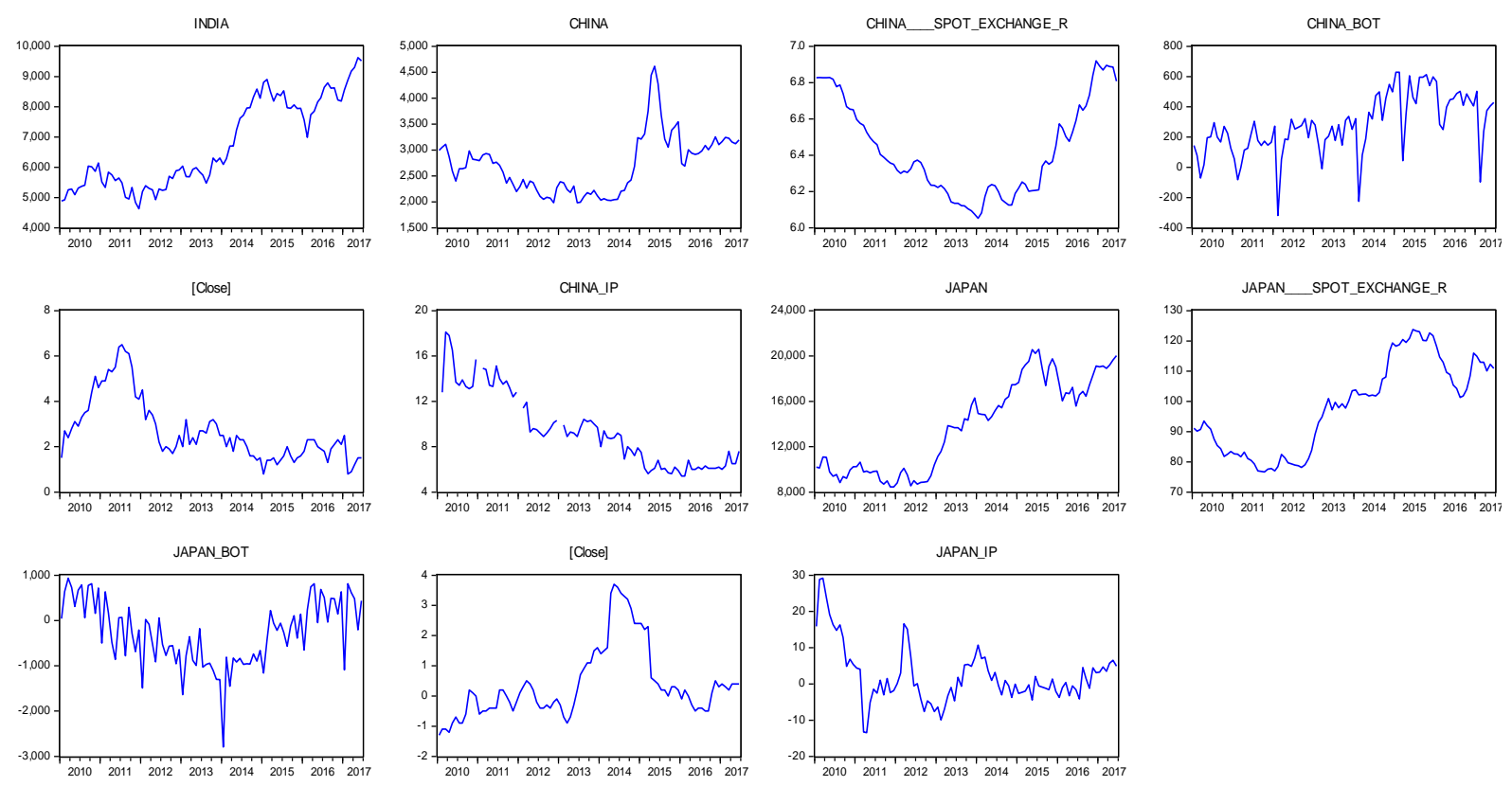

\subsubsection{Descriptive Statistics}

The descriptive statistics are shown in Table 1 indicates different figures of underlying variable properties under consideration in the study. The statistical analysis reveals mean, median maximumminimum and standard deviation values of the series. Further we can observe that all the variables are right skewed except China BoT and Japan BoT which are negatively skewed. Kurtosis statistic of the variables shows that the variables china and Japan IP are leptokurtic (long-tailed or higher peak) comparative to other variables which are platykurtic (short tailed or lower peak). Finally, the Prob. of the Jarque-Bera stat. shows the residual normality only for the two variables. 
Table 1

\begin{tabular}{|c|c|c|c|c|c|c|c|c|c|c|c|}
\hline & India & China & $\begin{array}{c}\text { China } \\
\text { Spot } \\
\text { Exch. }\end{array}$ & $\begin{array}{c}\text { China } \\
\text { Bot }\end{array}$ & $\begin{array}{l}\text { China } \\
\text { IP }\end{array}$ & $\begin{array}{l}\text { China } \\
\text { Infla }\end{array}$ & Japan & $\begin{array}{c}\text { Japan } \\
\text { Spot } \\
\text { Exch. }\end{array}$ & $\begin{array}{c}\text { Japan } \\
\text { Bot }\end{array}$ & $\begin{array}{c}\text { Japan } \\
\text { IP }\end{array}$ & $\begin{array}{c}\text { Japan } \\
\text { Infla }\end{array}$ \\
\hline Mean & 6743.9 & 2711.2 & 6.428 & 279.3 & 9.470 & 2.688 & 13839 & 98.21 & -276.5 & 2.2718 & 0.387 \\
\hline Median & 6112.0 & 2685.4 & 6.361 & 273.1 & 9.100 & 2.300 & 14316 & 99.873 & -238.3 & 0.2394 & 0.200 \\
\hline Max. & 9621.2 & 4611.7 & 6.919 & 628.3 & 18.10 & 6.500 & 20585 & 123.7 & 931.9 & 29.18 & 3.700 \\
\hline Min. & 4624.3 & 1979.2 & 6.050 & -319 & 5.400 & 0.800 & 8434 & 76.64 & -2795 & -13.4 & -1.30 \\
\hline Std.Dev. & 1446.0 & 560.52 & 0.257 & 194.6 & 3.274 & 1.375 & 4017 & 15.07 & 713.1 & 7.893 & 1.188 \\
\hline Skew. & 0.3367 & 0.9400 & 0.461 & -0.33 & 0.691 & 1.168 & 0.099 & 0.093 & -0.36 & 1.225 & 1.292 \\
\hline Kurtosis & 1.5980 & 4.1114 & 1.899 & 3.176 & 2.539 & 3.579 & 1.506 & 1.685 & 3.215 & 5.118 & 3.973 \\
\hline JB Stat. & 9.0717 & 17.889 & 7.732 & 1.796 & 7.613 & 21.74 & 8.509 & 6.614 & 2.191 & 39.37 & 28.59 \\
\hline Prob. & 0.0107 & 0.0001 & 0.020 & 0.407 & 0.022 & 0.000 & 0.014 & 0.036 & 0.334 & 0.000 & 0.000 \\
\hline
\end{tabular}

\subsection{STATIONARY PROCEDURE}

\subsubsection{Unit Root Test}

In the time series analysis the concept of stationary is an important aspect to be addressed before moving forward on the advance procedures because it is well known that most of the time series data sets have stationary concerns which needs to be handled slight differently than the traditional regression assumptions. The same applies in the case of ARDL methodology also. However as mentioned earlier, the ARDL procedure can be administered irrespective of order $\mathrm{I}(0), \mathrm{I}(1)$, Ouattara (2004) pointed out that if any variable is integrated at I(2) then computation of F-statistics for cointegration becomes spurious. Therefore, appliance of unit root tests is still necessary to ensure that no variable is integrated at $\mathrm{I}(2)$.

Table 2 reports the results of unit root test which has been derived from the application of most popular and widely used augmented dickey fuller (ADF) test. The table discloses the level and first difference data statistics for each variable at the $1 \%, 5 \%$ and $10 \%$ levels of significance. We can analyze from table 2 that most of the variables were non stationary at level t-statistic but after first differencing they became stationary. But the data series China BoT, Japan BoT and Japan IP were stationary at level at $1 \%, 10 \%$ and $5 \%$ respectively.

As of now, the results explicitly confirmed that no variable exist at order I(2) so we will move further to the co-integration procedure. 
Table 2

\begin{tabular}{|c|c|c|c|c|}
\hline Variables & Level & Probability & First Difference & Probability \\
\hline & $\mathrm{t}$-Statistic & & T-Statistic & \\
\hline India & -0.407902 & 0.9023 & -9.694074 & $0.0000 *$ \\
\hline China & -2.285527 & 0.1789 & -7.072446 & 0.0000 \\
\hline China Spot Exch. & -1.466796 & 0.5458 & -5.804906 & 0.0000 \\
\hline China Bot & -4.627560 & 0.0003 & - & - \\
\hline China IP & -1.913115 & 0.3247 & -8.720566 & 0.0000 \\
\hline China Inflation & -1.707885 & 0.4238 & -11.83152 & 0.0001 \\
\hline Japan & -0.363027 & 0.9099 & -8.588725 & 0.0000 \\
\hline Japan Spot Exch. & -0.929149 & 0.7746 & -6.737508 & 0.0000 \\
\hline Japan Bot & -1.788131 & $0.0702 * *$ & - & - \\
\hline Japan IP & -2.977566 & 0.0409 & - & - \\
\hline Japan Inflation & -1.798884 & 0.3789 & -7.638116 & 0.0000 \\
\hline \multicolumn{5}{|c|}{ *Denotes significance at $1 \%$ or $5 \%$} \\
\hline$* *$ Denotes signifi & $10 \%$ & & & \\
\hline
\end{tabular}

\subsection{CO-INTEGRATION RESULTS}

As per methodology, the co-integration test under the bounds testing entails comparing the $\mathrm{F}$ statistic value with the upper and lower critical values. Table 3 shows the value of $F$ statistic with the UBC and LBC levels and from these results the null hypothesis of no long run relationship is rejected at $1 \%$ level of significance As the table shows that the estimated F-statistic is greater than the upper bound critical values suggested by Narayan (2005) at the 1\% level signifies that long run co-integration exists between the variables when NSE or India taken as the dependent variable and other being the long run forcing variables.

Table 3

\begin{tabular}{cccccc} 
F- Bounds test & & \multicolumn{3}{c}{ Null: No levels Relationship } \\
Test Statistic & Value & Significance & $\mathrm{I}(0)$ & $\mathrm{I}(1)$ & Conclusion \\
F-statistic & 6.793065 & $10 \%$ & 1.85 & 2.85 & $\begin{array}{c}\text { Co- } \\
\text { integration }\end{array}$ \\
$\mathrm{K}$ & 10 & $5 \%$ & 2.11 & 3.15 & \\
& & $2.5 \%$ & 2.33 & 3.42 \\
& $1 \%$ & 2.62 & 3.77
\end{tabular}




\subsubsection{Long run estimates}

The table 4 shows the estimated parameters of the long run co-integration model. To obtain these results AIC criteria was used for the purpose of settling optimal lag length. Because AIC model is popular for its parsimonious characteristics, which selects the smallest possible lag length and it also minimizes loss of degree of freedom (Boutabba, 2014).

The highlighted variables (China BoT, Japan, Japan Spot Exchange and Japan Inflation) in the table are statistically significant at $5 \%$ level of significance. These variables are the long run co integrating variables with the dependent variable i.e. India.

The results indicate a negative but significant long run impact of china balance of trade on Nifty 50 index. That interpret $1 \%$ increase in the china balance of trade will cause $.001 \%$ decrease in the Indian stock index. This suggests that a bad news on global context will trigger negative impact on the index. Whereas, neither the Chinese stock index (SSE composite) nor any other economic variable have any impact on the index.

Further, the Japanese stock index (Nikki 225) has also negative but significant long run impact on the Indian index. Though the impact seems to be minute in nature but we cannot accept the null at 5\% level of significance.

While the variables Japan spot exch. and Japan inflation have positive and significant long run impact on the Indian index. A $1 \%$ increase in each variable will cause $0.05 \%$ and $0.20 \%$ increase in the Nifty 50 index respectively. This implies that as the Japanese policies follows negative or towards zero concepts in certain cases like interest rates, inflation rate, exchange rate etc. Hence a negatively increase in the Japanese spot exch. and inflation rate positively impacts the Indian index and these economic news might be treated as a good sign on the global context.

Table 4

Long Run Estimates

$\begin{array}{llcc}\text { Coefficient } & \text { Std. Error } & \text { T-statistic } & \text { Probability } \\ -0.000335 & 0.000218 & -1.533044 & 0.1333 \\ 0.923915 & 0.577262 & 1.600513 & 0.1176 \\ -0.001330 & 0.000625 & -2.127812 & 0.0397^{*} \\ -0.055626 & 0.065764 & -0.845841 & 0.4028 \\ -0.073365 & 0.101373 & -0.723714 & 0.4736 \\ -0.000223 & 9.35 \mathrm{E}-05 & -2.381382 & 0.0222^{*} \\ 0.057081 & 0.021583 & 2.644699 & 0.0117 * \\ 5.06 \mathrm{E}-05 & 0.000309 & 0.163428 & 0.8710 \\ -0.001755 & 0.013354 & -0.131445 & 0.8961 \\ 0.209445 & 0.092546 & 2.263155 & 0.0293^{*} \\ -6.408920 & 4.357575 & -1.470754 & 0.1494\end{array}$




\subsubsection{Short Run Estimates}

The table 5 discloses the estimated parameters of the short run dynamics of the model. The highlighted variables represent the state of being statistically significance. The coefficient ECM on lagged is significant with the correct sign at $1 \%$ level of significance, which supports the evidence of a stable long run relationship among the variables.

The elasticity of Indian index in context of selected variables of China i.e. China inflation, and China IP is significant $1 \%$ and $5 \%$ level of significance. Which shows that the china stock market index and the China inflation are significantly negatively correlated in short run with Indian stock index. Whereas, the China IP and Indian stock index are positively and significantly correlated in short run equilibrium. The coefficient values suggest that there is a minute negative impact of the Chinese financial index but the China inflation negatively and significantly impact the Nifty index as $1 \%$ increase in the Chinese inflation will cause $0.26 \%$ decrease in the short run while, a $1 \%$ increase in the China IP variable will cause $0.10 \%$ increase in the Nifty index on the short run as well.

The elasticity of Nifty index in terms of selected Japanese variables is significant for Japan index, Japan spot exchange, Japan BoT, and Japan inflation at $1 \%$ or $5 \%$, and $10 \%$ level of significance. This implies that the Japanese stock index and Japan inflation significantly and positively impacting the nifty index in the short run. While the variables Japan spot exchange. And Japan BoT are negatively but significantly impacting the index. The values of the coefficients states that a $1 \%$ negatively increase in the Japanese inflation will cause $0.33 \%$ increase in the nifty index on the other hand a 1 unit increase in the Japan spot exchange will cause $0.03 \%$ decrease in the index. The coefficients values for Japan index and Japan BoT reveals that these variables in the short run have only a minute impact.

The diagnostic tests for the model are expressed in table 6 below which represents the robustness of the model in terms of statistically significant $p$ values. The results indicate that the model is free from serial correlation which is confirmed by both the serial correlation LM test and the Durbin Watson statistic. Further, the residuals are normally distributed and there exist no heteroskedasticity among them. The value of $\mathrm{R}^{2}$ is good and well above the acceptable level. The AIC criteria also report the model selection value at optimum lag lengths. Therefore, the outcome of the diagnostic tests indicate that the model have all the desired econometric properties.

Table 5

Short Run Estimates

\begin{tabular}{llll} 
Coefficient & Std. Error & T-statistic & Probability \\
-0.000596 & 0.000245 & -2.429573 & 0.0198 \\
-0.265151 & 0.105143 & -2.521818 & 0.0159 \\
0.106919 & 0.048037 & 2.225774 & 0.0319 \\
0.564125 & 1.228264 & 0.459286 & 0.6486 \\
0.000187 & 0.000348 & 0.536457 & 0.5947 \\
0.000381 & $7.80 \mathrm{E}-05$ & 4.891158 & 0.0000 \\
-0.034765 & 0.019957 & -1.741964 & 0.0894 \\
-0.000389 & 0.000127 & -3.064247 & 0.0039 \\
\hline
\end{tabular}




$\begin{array}{llll}0.330540 & 0.115676 & -2.857466 & 0.0068 \\ & & & \\ -0.001094 & 0.014246 & 0.076778 & 0.9392 \\ -1.454087 & 0.142237 & -10.22295 & 0.0000\end{array}$

\subsubsection{Diagnostic tests}

Table 6

Next, the Graph 2 and Graph 3 present the CUSUM and CUSUMSQ parameter stability plots which apply to test the stability of the model. Both these plots are updated recursively and plotted against the break points. Both these plots should remain and move across within the 5\% level of significance bounds. The graphs show the plots are within and moving across the two critical bounds, implying that the coefficients in the error correction model are stable.

Graph 2

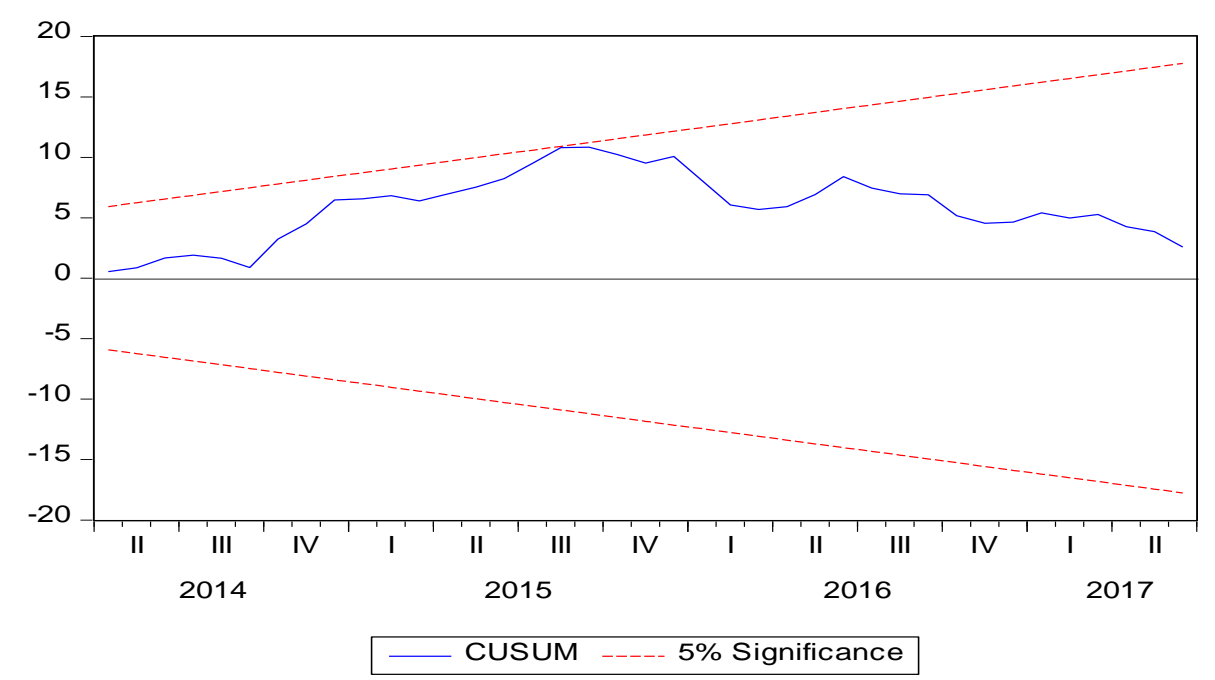


Graph 3

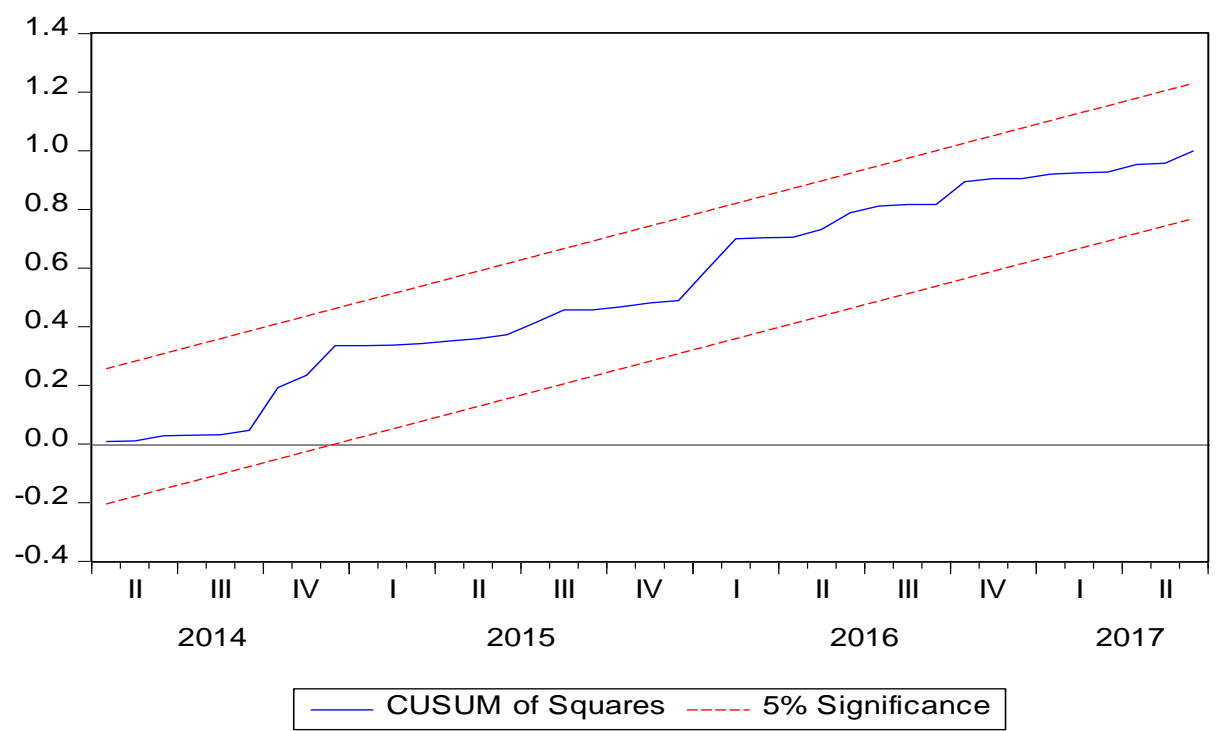

\subsection{GRANGER CAUSALITY RESULTS}

Although the evidence found so far has exposed the long run equilibrium relationship between India, Japan and China. The below table 7 holds Toda and Yamamoto (1995) Granger causality test results which shows the direction of causality among the variables and also cross validating the ARDL bounds testing results.

The highlighted figures in table 7 confirm the presence of causality between the selected variables. As we can detect in terms of China the China IP variable is statistically significant at $5 \%$ level of significance. This means that there is a unidirectional causality running from China IP to the Indian stock market in the short run. In terms of Japan the Japan stock index, Japan BoT, Japan IP and Japan Inflation are statistically significant at $10 \%$ and $1 \%$ levels of significance corroborating the running of unidirectional causality to the Indian stock market. Besides, the overall significance of all the variables is significant at 5\% critical level which divulges the consistency of these short and long run evidence with the ARDL bounds testing short run and long run estimates.

Table 7

Dependent variable - India

Sources of Causation

China

China Spot Exch.

China BoT

China IP

China Inflation

Japan
6.666562

1.362917

Lags $=3$

F Statistic

Probability

0.2653

0.5816

0.3737

$0.0477^{*}$

0.2532

$0.0833 * *$

0.7142 


\begin{tabular}{|c|c|c|}
\hline Japan BoT & 13.33811 & $0.0040 *$ \\
\hline Japan IP & 6.553016 & $0.0876 * *$ \\
\hline Japan Inflation & 7.469273 & $0.0584 * *$ \\
\hline All & 49.03725 & 0.0156 \\
\hline
\end{tabular}

*Denotes significance at $1 \%$ or $5 \%$

** Denotes significance at $10 \%$

\subsection{CONCLUSION}

This study endeavours to examine the long run and short run equilibrium impact of Japan and Chinese financial markets on Indian stock market. Secondly, to analyze the impact of selected variables (exchange rate, balance of trade, inflation rate and industrial production) of Japan and china on India and third, to trace the presence of temporal causality from these selected markets to India in the post crisis era by applying the Autoregressive Distributed Lag (ARDL) bounds testing procedure (Pesaran 2001) and Toda Yamamoto (1995) granger causality technique.

The results advocate the presence of both long and short run equilibrium impacts from the selected variables on India. The long run estimates suggest that the financial market of Japan (Nikki 225 stock index) has a trivial negative but significant impact whereas, the Chinese stock index (SSE composite) is operating at the short run with the same mild negative but significant impact on the Indian stock market.

Apart from this, the impact of macroeconomic variables on the long run has found only in case of BoT in terms of China while in context of Japan, the Japan spot exchange and Japanese inflation are cointegrating with Indian stock market.

Further, the results of error correction dynamics suggested that in the short run China inflation and China IP are significantly impacting the Indian market whilst from Japan all the variables except Japan IP have short run equilibrium relationship with the nifty index. These findings are well aligned with the previous studies such K. Lingaraja et. al. (2012), P. Chougala1 and H.S. Srivastsa, B. S. Veerappa, A. Bhunia and A. Das (2012). However studies such as P. Joshi (2011) M. Anees and S. Kumar (2014) discovered oposite evidence and found no clues of integration.

Additionally, to discover the temporal causality from the selected variables to the Indian market and for cross examining our obtained evidence we moved one step further and applied the granger causality test which unveiled that the unidirectional causality exists from china IP, Japan, Japan BoT, Japan, IP, and Japan Inflation towards the Indian financial market. These results are supported by the studies Bhatia (2014), M Babu, C Hariharan and S Srinivasan (2016).

\section{REFERENCES}

[1] Engle, R.F., Granger, C.W.J. (1987) Co-integration and error correction: representation, estimation and testing. Econometrica 55, 251-276

[2] Johansen, S., Juselius, K. (1990) Maximum likelihood estimation and inference on co-integration with applications to the demand for money. Oxford Bull. Econ. Stat. 52(2), 169-210

[3] Phillips, P.C.B., Hansen, B.E. (1990) Statistical inference in instrumental variables regression with I(1) processes. Rev. Econ. Stud. 57(1), 99-125

[4] Toda, H.Y., Yamamoto, T. (1995) Statistical inferences in vector autoregressions with possibly integrated processes. J. Econom. 66, 225-250

[5] Pesaran, M.H., Pesaran, B. (1997) working with Microfit 4.0: interactive econometric analysis. Oxford University Press, Oxford

[6] Zapata, H.O., Rambaldi, A.N. (1997) Monte Carlo evidence on co-integration and causation. Oxford Bull Econ. Stat. 52, 285-298

[7] Pesaran, M.H., Shin, Y. (1999) an autoregressive distributed lag modelling approach to co-integration analysis. In: Strom, S. (eds.) Econometrics and economic theory in 20th Century: the Ragnar Frisch 
Centennial Symposium, Chapter 11, Cambridge University Press, Cambridge

[8] Pesaran, M.H., Shin,Y., Smith, R.J. (2000) Structural analysis of vector error correction models with exogenous I(1) variables. J. Econom. 97, 293-343

[9] Pesaran, M.H., Shin, Y., Smith, R.J. (2001) Bounds Testing Approaches to the Analysis of Level Relationships. J. Appl. Econom.. 16, 289-326

[10] Haug, A. (2002) temporal aggregation and the power of co-integration tests: a Monte Carlo study. Oxford Bull. Econ. Stat. 64, 399-412

[11] Laurenceson, J., Chai, J.C.H. (2003) financial reform and economic development in China. Edward Elgar, Cheltenham, UK

[12] Ouattara, B. (2004) Foreign Aid and Fiscal Policy in Senegal. Mimeo University of Manchester, Manchester.

[13] Gay, R. D., Jr. (2008). Effect of Macroeconomic Variables on Stock Market Returns for Four Emerging Economies: Brazil, Russia, India, and China. International Business \& Economics Research Journal, 7(3), 1-8.

[14] Sanati, G. (2010). Integration of India's Financial Markets on the Domestic and International Fronts: An Empirical Analysis of the Post-Liberalisation Period. Working Paper, 431, 4-70.

[15] Singh, G., \& Singh, P. (2010). Chinese and Indian Stock Market Linkages with Developed Stock Markets. Asian Journal of Finance \& Accounting, 2(2), E2, 21-39.

[16] Joshi, P. (2011). Return and Volatility Spillovers among Asian Stock Markets. SAGE Open, 1-8.

[17] Marelli, E., \& Signorelli, M. (2011). Openness, Trade and Effects on Economic Growth. The European Journal of Comparative Economics, 8(1), 129-154.

[18] Shahbaz, M., \& Feridun, M. (2011). Electricity consumption and economic growth empirical evidence from Pakistan. Springer.

[19] Bhunia, A., \& Das, A. (2012). Financial Market Integration: Empirical Evidence from India and Select South Asian Countries. International Journal of Scientific \& Engineering Research, 3(3), 1-6.

[20] Chougala, P., \& Srivastsa, H.S. (2012). Analytical Study of Correlation between Indian and International Stock Market [Abstract]. Faculty of Management and Commerce, Ramaiah University of Applied Sciences, 27-30.

[21] Srikanth, P., \& Aparna, K., Dr. (2012). Global Stock Market Integration - A Study of Select World Major Stock Markets. Journal of Arts, Science \& Commerce, 3(1), 203-2011.

[22] Glick, R., \& Hutchison, M. (2013). China's Financial Linkages with Asia and the Global Financial Crisis. Federal Reserve Bank of San Francisco Working Paper Series, 1-43

[23] Anees, M., \& Kumar, S. (2014). Testing Random Walk Behaviour of Major Asian Stock Markets. Integral Review- A Journal of Management, 7(2), 76-86.

[24] Bhatia, A., \& Binny. (2014). Analysis of Stock Market Volatility: A Comparative Study of India and China. Apeejay Journal of Management and Technology, 9(2), 8-17.

[25] Boutabba, A. (2014). The Impact of Financial development, income, energy, and trade on carbon emissions: Evidence from Indian economy [Abstract]. Economic Modelling, 33-41.

[26] Patel, S. A. (2014). Causal and Co-integration Analysis of Indian and Selected Asian Stock Markets. Drishtikon: A Management Journal, 5(1), 37-52.

[27] Veerappa, B. (2014). Co-integration of Asian Stock Markets: Empirical Evidence from India. Department of Studies and Research in Economics

[28] Lingaraja, K., Selvam, M., \& Venkateswar, S. (2015). An Empirical Examination of Returns on Select Asian Stock Market Indices. Journal of Applied Finance \& Banking, 5(2), 97-101.

[29] Arslanalp S. et. al. (2016). China's Growing Influence on Asian Financial Markets. IMF Working Paper Asia and Pacific Department.

[30] Babu, M., Hariharan, C., \& Srinivasan, S. (2016). Inter Linkages of Asian Pacific Stock Markets: An Empirical Study. Amity Journal of Finance, 1(1), 48-56.

[31] Mobarek, A. (unknown). Global Stock Market Integration and the Determinants of Co-movements: Evidence from developed and emerging countries. Stockholm University Business School, 1-61. 